\title{
A Arte Relacional e a Participação do Público: Aproximações Poéticas do Período de 1960-70 Com A 27ª Bienal de São Paulo
}

\author{
Luana Hauptman Cardoso de Oliveira ${ }^{1}$ \\ AmÉlia Siegel CorrêA
}

\begin{abstract}
Resumo
O conceito de Estética Relacional baseia-se em uma construção poética centrada nas relações humanas e sociais e geralmente é pensada fora do ambiente das instituições artísticas. Esta prática ganha força a partir da década de 1960-70 e se destaca na poética de Hélio Oiticica, principalmente na obra Parangolé. Contudo, a conceitualização do tema acontece apenas em 1990 pelo crítico francês N. Bourriaud, que desconsidera o trabalho de Oiticica e foca suas análises em artistas europeus do final do século XX. Por fim, apesar destas intenções poéticas remeterem à década de 1960, elas foram celebradas institucionalmente no cenário brasileiro apenas em 2006, na 27ª Bienal de São Paulo. O artigo busca, desta forma, refletir sobre os desencontros conceituais e as temporalidades distintas que perpassam os três eventos mencionados.
\end{abstract}

Palavras-chave: Arte relacional. Público de arte. Arte contemporânea. Campo artístico.

1 Especialista em História Social da Arte pela PUC/PR e mestranda em História pela Universidade Federal do Paraná (UFPR), Brasil. luana_hdeoliveira@yahoo.com.br

2 Doutora em Sociologia pela USP e Pós-doutoranda em Sociologia pela UFPR, é também professora do curso de especialização em História Social da Arte da Pontifícia Universidade Católica do Paraná (PUC/PR), Brasil. ameliascorrea@icloud.com 


\title{
Relational Art and Audience Involvement: Poetic Approaches From 1960-70s at the 27th São Paulo Art Biennial
}

\begin{abstract}
The concept of Relational Aesthetics is based on a poetic construction centered on human and social relationships, and it is usually thought outside the artistic institutions environment. This kind of practice gets stronger in the 1960s and the 1970s, and it stands out on the poetry of the artist Hélio Oiticica, mainly on his work entitled Parangolé. However, the conceptualization of this theme happens only in 1990, by the french critic Nicolas Bourriaud, who disregards Oiticica's work, focusing his analysis on the work of European artists from the end of the 20th Century. Finally, although these poetic intentions refer from the 1960s, they were institutionally celebrated inside the Brazilian scene only in 2006, at the 27th São Paulo Biennial. This article seeks, therefore, to reflect upon these conceptual mismatches and the different temporalities that runs through the three above-mentioned events.
\end{abstract}

Key-words: Relational art. Art audience. Contemporary art. Artistic field.

\section{Preâmbulo ${ }^{3}$}

A proposta curatorial da $27^{a}$ Bienal de São Paulo realizada em 2006 se apresenta como desenrolar de um processo artístico iniciado em 1960 por Hélio Oiticica. Este artista, entre outros do cenário brasileiro, apresentou como poética de trabalho os mesmo critérios defendidos por Nicolas Bourriaud para a Estética Relacional. Curiosamente, o conceito do crítico francês foi embasado em obras de arte realizadas por artistas europeus no período de 1990, ou seja, é bastante posterior ao trabalho de Hélio Oitica. O objetivo deste artigo é realizar aproximações entre a poética de Hélio Oiticica como precursor deste discurso e o conceito de Nicolas Bourriaud referente à Estética Relacional.

Ainda dialogando com conceitos, a escolha da $27^{a}$ Bienal de São Paulo como outro elemento de aproximação justifica-se pela

3 Gostaríamos de agradecer a leitura atenta e cuidadosa e os comentários dos avaliadores deste artigo. 
inovação curatorial definida por Lisette Lagnado, o que garantiu grande repercussão da exposição e permitiu um confronto entre o conceito do crítico francês e as práticas realizadas no Brasil nas décadas de 1960 e 1970. Através da exposição, vemos aproximações entre os conceitos estéticos da Bienal e os discursos dos artistas, que buscaram estabelecer novos diálogos entre a arte contemporânea e o público, colocando-se como parte ativa das discussões referentes aos novos papéis do espectador de arte e das instituições.

Faz-se necessário lembrar que estes possíveis novos paradigmas da arte contemporânea remetem a práticas artísticas anteriores ao conceito de Estética Relacional de Nicolas Bourriaud e tais relações conversam tanto com a $27^{a}$ Bienal de São Paulo como também com as práticas artísticas do período de 1960-1970 de Hélio Oiticica. $\mathrm{O}$ fato de Bourriaud ter excluído de suas análises as obras do artista brasileiro serão examinadas com o auxílio da teoria de campo do sociólogo francês Pierre Bourdieu. Este olhar para dentro do campo da arte mostra-se necessário pois traz à tona as disputas e jogos de poder, como no caso da menor importância dada às práticas de um artista periférico em relação ao centro da produção artística mundial, num confronto binário entre centro e periferia, evidente no discurso de Bourriaud.

A partir das análises de Bourdieu (1996, 2003) sobre o funcionamento do campo da arte, entende-se que é na modernidade, quando a arte atinge seu auge como bem simbólico, que as analogias entre arte e vida e as relações com o público se acentuam. Já mais contemporaneamente, as tensões dentro do campo da arte levam a um afastamento entre receptor e arte, pois a própria arte passa a exigir das pessoas maior entendimento das trocas e dos códigos simbólicos para poder participar dos processos de fruição. Este fator ajuda a compreender as diretrizes da curadoria da $27^{\mathrm{a}}$ Bienal de São Paulo e sua preocupação com a preparação de um material educativo voltado 
ao público, assim como a escolha da gratuidade no acesso à exposição, questões que conversam diretamente com as preocupações estéticas dos artistas que abordam esta temática e que procuram, se não sanar, minimizar a elitização da arte por meio das instituições artísticas e de seus agentes. Ao privilegiar a ação educativa da exposição, a curadoria aposta na ideia de que um potente projeto pedagógico é peça central para que o evento atinga seus objetivos civilizatórios (OLIVEIRA, 2001, p. 27).

Seguindo a linha de pensamento da sociologia da arte de Bourdieu, o público não inteirado das novas discussões estéticas permanece à margem mesmo quando as práticas arísticas buscam estabelecer com ele uma relação mais próxima. Apesar da tal esforço, o contato do público com os objetos artísticos mantêm-se em um nível muito raso de conhecimento, apoiando-se em questões de gosto pessoal e beleza ${ }^{4}$, pela falta de familiaridade com os códigos internos, o que acontece principalmente no caso da arte contemporânea, dificultando a recepção da obra e a desmitificação do "cubo branco". Assim, a familiaridade com a "arte retiniana" da qual falava Duchamp, ou então dos códigos artísticos anteriores ao modernismo, permitia uma fruição mais acessível às pessoas de um modo geral, tanto pela proximidade da mensagem com o público quanto pela existência de temas mais facilmente detectáveis.

Para Bourdieu (1996, p. 259), um objeto artístico se 'transforma' em obra de arte quando passa a ser "conhecida e reconhecida, ou seja, socialmente instituída como obra de arte por espectadores dotados da disposição e da competência estéticas necessária para conhecer e reconhecer como tal". Mas, a partir da década de 1960 e de acordo com Bourriaud (2009, p. 24) a dinâmica de relacionamento espectador

4 Vale notar que a ideia de um "gosto pessoal" é uma crença de senso comum, que não faz sentido na sociologia de Bourdieu (2007). O autor faz justo o contrário: desnaturaliza as preferências estéticas individuais, revelando que elas derivam de disposições internalizadas ao longo da vida, que compõem o habitus, e que a construção do gosto leva à distinção social. 
- obra de arte passa a ser "regida por outros princípios". Assim, "uma exposição criará, segundo o grau de participação que o artista exige do espectador, a natureza das obras, um 'domínio de trocas' particular", relação que será proposta tanto nas obras de Hélio Oiticia, como no projeto curatorial da 27 ${ }^{a}$ Bienal de São Paulo, dispensando que o público seja conhecedor de critérios e discussões formais e conceituais, elevando o contato com a arte ao nível de relacionamento.

Ainda assim é importante destacar que, apesar desse novo jogo de trocas "é cada vez mais raro que o deleite não tenha por condição a consciência e o conhecimento dos jogos e das apostas históricas dos quais a obra é produto" (BOURDIEU, 1996, p. 280), e por maior que seja o envolvimento do público no processo de criação ou execução da obra de arte, a criação conceitual se utilizará de referências internas que muitas vezes são restritas ao campo. Assim, apesar de certas propostas inovadoras, a falta de conhecimento dos processos estéticos contemporâneos leva a "desencontros entre modernização social e modernismo cultural, entre política de elite e consumo massivo, entre inovações experimentais e democratização cultural." (CANCLINI, 2000, p.150). Logo, as constantes reorganizações dentro do campo que aparentemente propõe interpretações livres e tentam abrir fronteiras, podem ser percebidas pelo público não consumidor de arte com algum receio.

Dentro de um diagnóstico contemporâneo da arte apontado por Nestor Canclini, “analisar a arte já não é analisar apenas obras, mas as condições textuais e extratextuais, estéticas e sociais, em que a interação entre os membros do campo gera e renova sentido" (CANCLINI, 2000, p. 151). É, portanto, "uma forma de arte cujo substrato é dado pela intersubjetividade e tem como tema central o estar-juntos, o 'encontro' entre observador e quadro, a elaboração coletiva do sentido" (BOURRIAUD, 2009, p. 21), uma estética de relacionamento. Assim, nestas ações relacionais o público passa a agir 
sobre o campo e seu papel frente à arte se altera, completando-a como "um elemento de ligação, um princípio de aglutinação dinâmica" (BOURRIAUD, 2009, p. 29), instável e dependente, que existe a partir e por conta de encontros aleatórios que envolvem de forma dinâmicas as relações humanas.

Os debates acima, embora desenvolvidos em outro momento, aproximam-se da estética desenvolvida nos anos 1960-1970 pelo artista neocontreto brasileiro Hélio Oiticica. Partindo das experiências e das novas formas de habitar o mundo, com novos modelos de sociabilidade, ele toma como ponto de partida as relações humanas, atitude bastante vanguardista no contexto artístico no qual trabalhava. Na obra Parangolé, o artista propõe vínculos perceptivos e estruturais com o público. A cor, elemento formal da arte, é trazida por Oiticia para o âmbito estrutural, o que permite que as assimilações sejam potencializadas, uma vez que este elemento que deveria estar contido toma o espaço e o tempo, fazendo com que seja percebido espacialmente como objeto, em um nível de participação corporal direta.

Neste sentido o objeto/elemento só se transforma em arte quando a ação acontece. Assim, Oiticica torna ainda mais relativo o espaço e "transforma a tríplice perfomance-espaço-tempo na obra, ou como ele mesmo pontua, 'obra-ação'." No caso dos Parangolés, a necessidade de 'usar' a obra "é um ato que exige do espectador uma vivência e seu corpo se torna núcleo estrutural da obra. Aí se verifica a inter-relação espectador-obra e sua subjetividade nessa vivência" (MELO et al., 2012, p. 67), fazendo com que a improvisação permita uma fruição estética que não exige um conhecimento específico do campo artístico, conectando indivíduo, coletivo e estruturando relações. Estas ocorrem de forma menos mediada e mais espontânea, ao deslocar o objeto artístico para o espaços públicos, ao ar livre, sugerindo lugares que sejam livres à participação e invenção de uma criação que se concretiza como coletiva. 
Desta forma, como salienta Bourriaud, o objetivo da estética relacional não éo convívio simplesmente, mas o produto desse convívio, numa forma complexa que reúne estrutura formal e objetos postos à disposição do público refletindo o comportamento coletivo, gerando microutopias funcionais dentro do corpo social, com novos modelos de vida dentro da realidade e não com a alteração do que já está posto.

\section{Da Arte Relacional}

... examinar a ciência na ótica do artista, mas a arte na da vida.

- Nietzsche

Os livros de Nicolas Bourriaud sobre Estética Relacional foram publicados na França a partir de 1998, e embora suas traduções no Brasil tenham chegado apenas em 2009, muito antes desta data os conceitos de Bourriaud já eram conhecidos por aqui. Em Estética Relacional (2009) o autor teoriza a partir de trabalhos artísticos europeus dos anos 1990 sobre possíveis novos questionamentos e paradigmas da arte contemporânea, como interatividade e hibridização das linguagens. Ao eleger trabalhos do final do século $\mathrm{XX}$, ignora a produção de Hélio Oiticica, que já explorava estes conceitos nos anos 1960, e que certamente eram conhecidos pelo autor. A justificativa de Bourriaud é que, ao contrário da produção artística de 1960-1970, na geração de 1990 "a questão não é mais ampliar os limites da arte, e sim testar sua capacidade dentro do campo social global" (BOURRIAUD, 2009, p.43), justificativa que não convenceu os críticos e artistas

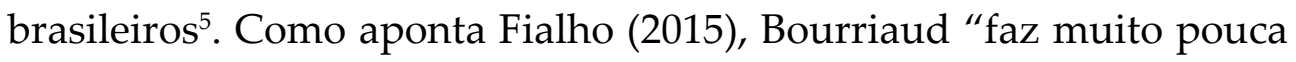
referência aos antecedentes de sua estética relacional. [...] o problema mais grave nas propostas de Bourriaud não se refere à estética que ele defende, mas a fragilidade de seus fundamentos teóricos. Existe no livro um certo eurocentrismo [...]" ou, em outras palavras, uma postura colonialista. Estes desencontros podem ser encarados como

5 Essa polêmica pode ser percebida através do relato da palestra de Nicolas Bourriaud no

Seminário Internacional Trocas, 10 de outubro de 2006.(FIALHO, 2015). 
tensões dentro do campo que sempre privilegiam o centro (arte internacional/europeia e americana) em detrimento da periferia (arte nacional/latino-americana) ${ }^{6}$.

Mas, a despeito disso e de acordo com Bourriaud (2009, p. 151), estética relacional é um "conjunto de práticas artísticas que tomam como ponto de partida teórico e prático o grupo das relações humanas e seu contexto social, em vez de um espaço autônomo e privativo", ou seja, é um segmento da arte contemporânea que se concentra nas relações diretas entre espectador e obra.

É certo que a arte esteve habitualmente, em graus distintos, relacionada às relações humanas e a seus contextos sociais, podendo "ser lida como uma história dos sucessivos campos relacionais externos, que mudam de acordo com as práticas determinadas por sua própria evolução interna." (BOURRIAUD, 2009, p. 41-42), o que está de acordo com Bourdieu e as tensões dentro do campo como espaço de trocas. No entanto, a partir de começo do século XX, com o avanço tecnológico vivenciado pela sociedade europeia e norte-americana, novas realidades pediam inovações conceituais e os artistas passaram a explorar novos temas fazendo com que a arte ultrapassasse suas próprias classificações. Ainda assim, as ações permaneciam restritas ao meio e os discursos continuavam velados por barreiras institucionais e intelectuais que não permitiam a um público mais amplo tomar parte destas discussões, criando um buraco conceitual e estético entre apreciação e fruição da obra que só aumentava com o passar do tempo.

6 É oportuno remeter este modelo de análise a Ginzburg e Castelnuovo (1991), que apontam que esta relação não é apenas de difusão, mas perpassa a esfera das disputas.Na mesma direção, Alain Quemin (2001) tem problematizado este modelo mostrando que, mesmo no centro, há abismos e tensões. Na referida pesquisa, o autor francês mostra que no que concerce às exposições de arte contemporânea, os Estados Unidos tem um peso muito maior nos rumos do mercado que a Europa. Poderíamos pensar, então, dentro do escopo deste artigo, a partir do conceito de "universais do norte" (North atlantic universals") de Trouillot (2002), para nos referirmos a um sistema de valores oriunos do norte e com grande influência no sul. 
A partir da década de 1950, o panorama artístico começa a valorizar, além da obra final, o processo de criação do artista. Esta nova abordagem poética foi o ponto de partida para uma mutação maior dentro da arte contemporânea que se iniciou com as performances até chegar à estética relacional, onde a discussão sobre o papel do artista e do público em relação à obra de arte voltará a ser questionado:

Essa história, hoje, parece ter tomado um novo rumo: depois do campo das relações entre humanidade e divindade, a seguir entre humanidade e objeto, a prática artística agora se concentra na esfera das relações interhumanas, como provam as experiências em curso desde o começo dos anos 1990. (BOURRIAUD, 2009, p. 41-42)

Interessante observar como as teorizações de Bourriaud, que o autor faz questão de circunscrever à década de 1990, podem ser observadas em práticas artísticas já a partir dos anos 1960 no cenário artístico brasileiro, onde se constata a preocupação dos artistas em realizar produções em que "a prática artística apareça como um campo fértil de experimentações sociais, como um espaço parcialmente poupado à uniformização dos comportamentos."(BOURRIAUD, 2009, p. 13), o que por vezes ocorre apenas conceitualmente.

Apesar dos desencontros entre tradição e modernidade, tanto nas práticas quanto nas conceituações artísticas, as instituições, de maneira geral, têm procurado se reestruturar e práticas artísticas relacionais têm sido pensadas para acontecer dentro de museus e galerias, mas também para além desses espaços. Isto pode ser interpretado como uma necessidade do mercado da arte e de seus agentes em ampliar sua rede de conexão, expandindo-se economicamente para criar novos públicos, mas também passa por uma ressignifição do papel socialmente criado para estes ambientes que faz com que a arte, a partir da estética relacional, rompa com certas barreiras internas de seu campo. 


\section{Os Parangolés de Hélio Oiticica}

Hélio Oiticica (1937-1980) é um dos principais artistas da sua geração que desenvolveu um processo reflexivo sobre sua obra, construído de forma crítica, como se observa nos vários registros escritos deixados pelo artista. A partir de 1958, com o Grupo Frente do Rio de Janeiro e dentro de uma poética neoconstrutivista, sua trajetória foi se construindo até culminar no que o próprio artista chama de "construtivismo favelar". Através desta abordagem, Oiticica estabelece uma relação "imaginativo-estrutural" entre as construções e apropriações feitas no ambiente das favelas e sua obra "na relação pluridimensional que delas decorre entre 'percepção' e 'imaginação produtiva' (Kant), ambas inseperáveis, alimentando-se mutuamente" (OITICICA, 2011, p. 71), relacionando as questões formais da obra com o espaço-tempo.

Partindo de uma dissidência carioca do movimento concreto, responsável pelas principais produções e debates artísticos daqueles anos, Oiticica dá o ponta-pé numa produção em que "o espaço da obra, até então contido nos limites da tela ou do volume escultórico, tendeu agora a derramar-se pelos espaços do mundo real" (FREITAS, 2013, p. 33) utilizando-o como referência e buscando na "constituição do mundo dos objetos, a procura das raízes da gênese objetiva da obra, a plasmação direta da mesma" (OITICICA, 2011, p. 68) em uma relação entre arte e vida.

Dentro deste contexto, a produção artística de Oiticica constitue-se não apenas em um parâmetro conceitual e prático, mas abrange novas relações formais de construção, extrapolando as esferas tradicionais da arte. Isto significa, analogamente ao conceito de Bourriaud que,

[...] além do caráter relacional intrínseco da obra de arte, as figuras de referência da esfera das relações humanas agora se tornaram 'formas' integralmente artísticas: assim, 
as reuniões, os encontros, as manifestações, os diferentes tipos de colaboração entre as pessoas, os jogos, as festas, os locais de convívio, em suma, todos os modos de contato e de invenção de relação representa hoje objetos estéticos passíveis de análise enquanto tais (BOURRIAUD, 2009, p. 40).

Segundo Oiticica, "trata-se da procura de 'totalidades ambientais' que seriam criadas e exploradas em todas as suas ordens, desde o infinitamente pequeno até o espaço arquitetônico, urbano etc." (OITICICA, 2011, p. 68). Assim, mesmo não tendo analisado a obra de Hélio Oiticica, as avaliações de Bourriaud cabem para as práticas do artista por conta das bases poéticas de estruturação de seu trabalho, que toma a vida e as relações humanas como elementos formais.

O tratamento estrutural, a transição da cor do quadro para o espaço ainda no início da década de 1960 e as experiências extremamente vivenciais do artista com a realidade das favelas do Rio de Janeiro, principalmente da comunidade da Mangueira, tiram o espectador de seu papel passivo 7 e colocam-no dentro da obra. Assim, "a arte parecia enfim pronta a participar do cotidiano que lhe rodeava. A 'representação', enquanto arranjo de elementos sobre um fundo simbólico, [...] objetos apresentados à experiência do espectador" (FREITAS, 2013, p. 34), transforma-se em propostas sinestésicas e não mais contemplativas, num movimento de resistência à estetização generalizada, criando microestruturas individuais ou coletivas.

A criação da 'capa' (já realizadas a 1 e 2) veio trazer não só a questão de considerar um 'ciclo de participação' na obra, isto é, um 'assistir' e 'vestir' a obra para sua completa visão por parte do espectador, mas também a de abordar o problema da obra no espaço e no tempo não mais como se

$7 \quad$ A ideia de passividade do espectador, difundida a partir da Escola de Frankfurt, foi revista pelos Estudos Culturais que, a partir de pesquisas de recepção, mostram que os produtos culturais são assimilados, ou recebidos, de formas diversas pelos indivíduos, e que uma série de variáveis sociais afetam formas de recepção. Desta forma, quando usamos o termo passivo neste artigo, o fazemos de forma um pouco caricata, com o intuito de marcar uma distinção entre uma arte "retiniana" e outra "relacional". 
fosse ela 'situada' em relação a esses elementos, mas como uma 'vivência mágica' dos mesmos (OITICICA, 2011, p. 73).

Neste período as discussões relativas à figuração (entendida genericamente como a tentativa de representar o reconhecível) giram em torno da "arte na esfera pública, o que se traduziu, nos anos 1960 e 1970, numa vocação à reinserção da 'arte' na 'vida', para utilizar termos da época" (FREITAS, 2013, p. 48). Esta prática, no entanto, antecede o período em que Bourriaud estabelece como início das produções relacionais e remete ao aumento da disponibilidade dos materiais utilizáveis na arte de uso cotidiano, percebidos em movimentos anteriores, como o dadaísmo e em técnicas de colagem, assembblage e o ready-made. Ainda assim, essas primeiras inserções da vida na arte podem ser compreendidas como parciais, pois não consideram o espectador como partícipe deste processo. Para Bourriaud, a obra de arte dentro do conceito da estética relacional acontece

[...] quando coloca em jogo interações humanas, a forma de uma obra de arte nasce da interação do inteligível que nos coube. Através dela o artista inicia um diálogo. A essência da prática residiria, assim, na invenção de relações entre sujeitos. Cada obra de arte em particular seria a proposta de habitar um mundo em comum (BOURRIAUD, 2009, p. 30-31).

Esta proposta se concretiza quando Hélio Oiticica propõe os Parangolés. Estruturas que passam a confrontar os paradigmas da forma, a função do artista perante a obra, que deixa de ser criador para ser o motivador da relação entre arte e espectador e, até mesmo o papel do receptor, que passa a ser pensado como participante. Mas antes de chegar à construção efetiva dos Parangolés, Oiticica já registra suas preocupações em relação às conexões da arte com a vida em seu trabalho. Segundo o artista:

Quanto mais não-objetiva é a arte, mais tende à negação do mundo para a afirmação de outro mundo. Não a negação 
negativa, mas a extirpação dos restos inautênticos das vivências do mundo, corriqueiras. Só assim seria lícita a exclamação diante da não-objetividade da arte. "Que sensação de fim de mundo" ou "de nada". O que é preciso é que o mundo seja um mundo do homem e não um mundo do mundo (OITICICA, 2011, p. 27).

O que o artista estabelece a partir daí é um diálogo entre sua prática e a matéria que expressa sua intenção poética. Desta forma, questões formais da arte como o suporte tornam-se um problema a ser resovido. Para o artista, "há o intermediário entre o sentido de espaço e estrutura e o espectador que recebe a ideia" (OITICICA, 2011, p. 41) que não cabem mais nas formas tradicionais de arte. Isto faz com que na obra de Oiticica a cor passe a ser estutura e não elemento e o suporte é extentido ao mundo real. A estrutura plana, mesmo que no espaço e não na tela como nos Núcleos, limita a forma que para o artista deve se confundir com a estrutura, assim como o espaço se mescla com o tempo. Nota-se claramente essa transição de suporte na obra do artista que leva a arte à vida:

Figura 1 - Transição de SUPORTES

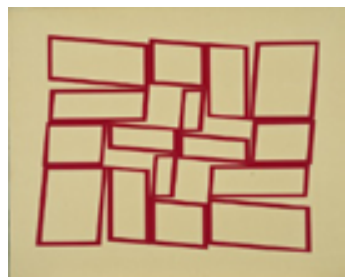

Metaesquema (1958)

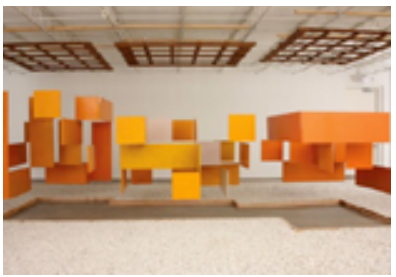

Núcleo1 (1960)

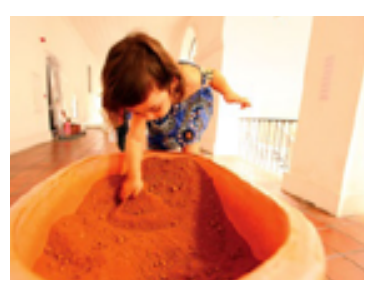

Bólide (1965)

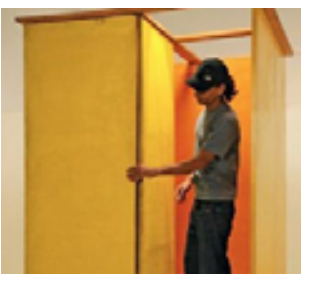

Penetrável - PN1 (1960)

Fonte: Autoras. 
É por volta de 1965 que os Parangolés se estabelecem no trabalho de Oiticica, em uma produção que procura "estabelecer relações perceptivo-estruturais" (OITICICA, 2011, p. 69) entre o espectador e a obra.

O Parangolé revela então o seu caráter fundamental de 'estrutura ambiental', possuindo um núcleo principal: o espectador-obra, que se desmembra em 'participador' quando assiste, e em 'obra' quando assistida de fora nesse epaço-tempo ambiental. Esses núcleos participadorobra ao se relacionarem (numa exposição, por exemplo) criam um 'sistema ambiental' Parangolé, que por sua vez poderia ser 'assistida' por outros participadores de fora (OITICICA, 2011, p. 74).

Esta estrutura cria uma rede de conexões e relacionamentos e "a proposição artística só se efetiva, de acordo com seu autor, se aquele que 'veste' os Parangolés estiver disposto, no ato de vesti-lo, a experimentar o espaço". A obra não precisa mais de um lugar si, "o que evidentemente se opõe à comercialização do mercado e à institucionalização dos museus, da mesma forma que impulsiona o homem - enquanto corpo e consenso - à condição de elemento 'figurado' no espaço que lhe envolve." (FREITAS, 2013, p. 62), tornando-se o próprio objeto da arte.

Assim, a proposta artística toma parte da vida e se coloca no mundo para acontecer, a instituição de arte não fica mais confinada ao cubo branco e se manifesta na mundo, se materializando como uma "necessidade coletiva de uma atividade criadora latente, que seria motivada de um determinado modo pelo artista" (OITICICA, 2011, p. 79), mas pensada para a participação, sendo necessária a disposição por parte do participador, uma ativação, para que, enfim, o processo se conclua através de uma realização criativa. 


\section{Figura 2 - Parangolé}

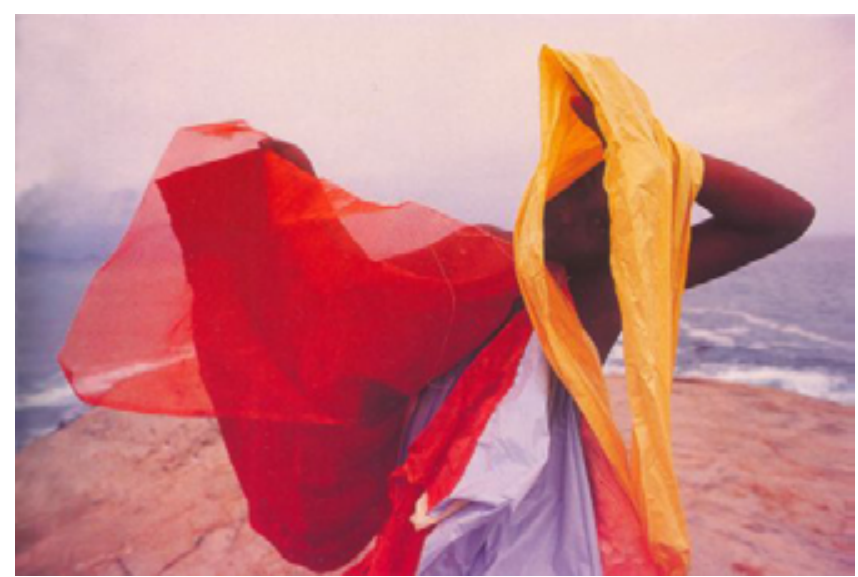

Fonte:IMMA (1964).

A participação do público para Oiticica a partir dos Parangolés "é uma 'participação ambiental' por excelência. Trata-se da procura de 'totalidades ambientais' que seriam exploradas e criadas em todas as suas ordens [...]" (OITICICA, 2011, p. 68) como um encontrar de elementos totais que excluem a classificação de vulgar e erudito na arte e transformam-na em experiências. Este referencial está presente na produção de outros tantos artistas deste período no Brasil, como Ligia Pape e Lígia Clark, e que portanto possuem os elementos centrais do que será desenvolvido no conceito de estética relacional.

\section{A 27 Bienal de São Paulo}

Uma vez que Bourriaud exclui a produção brasileira dos anos 1960-1970 da sua análise de obras que engendram a construção do conceito de estética relacional, tomou-se a $27^{\mathrm{a}}$ Bienal de São Paulo como parte deste artigo afim de aproximar a teoria do crítico francês e as práticas artísticas no contexto globalizado atual. Outros três fatores também contribuíram para esta decisão: 1) possibilita um olhar para a arte contemporânea mundial a partir de um evento, que mesmo 
internacional, parte de uma concepção nacional; 2) pode ser visto como a consagração de uma poética que tem início na década de 1960 e que ainda hoje produz ecos na arte contemporânea e, 3) mostra a procupação da curadoria do principal evento de arte contemporânea do país em não ser apenas um lugar para guardar e preservar as obras, mas sim como espaço de trocas com intenção de maximizar a aproximação entre arte e público.

De forma geral, os modelos expositivos procuraram ao longo da história da arte adaptar-se às novas formas de produção artística. SegundoSant'anna (2010, p. 28) que faz uma análise da mesma 27 $7^{\text {a Bienal }}$ de São Paulo, "já no início do século XX, os procedimentos artísticos modernos exigiam das exposições novos padrões que atendessem as necessidades de montagem, de modo que facilitassem as possíveis interpretações do público". Assim, a ação da curadoria se apresenta como uma ferramenta facilitadora da experiência estética, mediando a interação entre arte e público, mas também como propositora de novos conceitos. Para Lisette Lagnado (2006, p. 53):

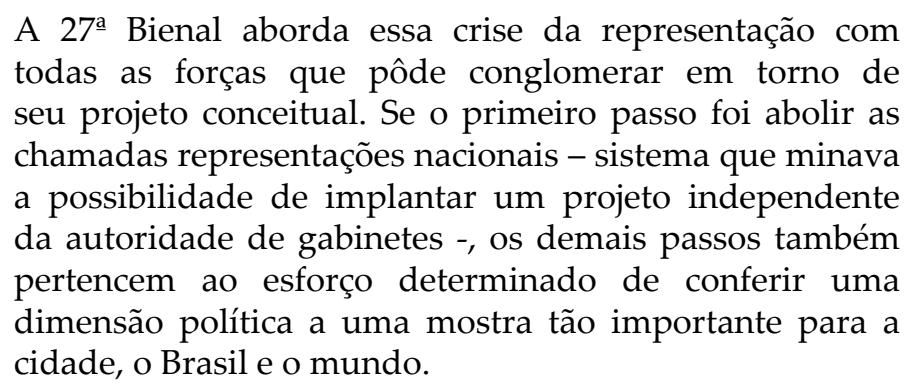

O discurso curatorial enfatiza, pois, um caráter político no sentido de "tratar de princípios da lei, do poder e da comunidade" (RANCIÈRE apud LAGNADO, 2006, p. 54) alvitrando "distintos graus de viver-junto", não apresentados como um manual de instruções, mas como um questionamento às inúmeras possibilidades de convivência. O título da $27^{a}$ Bienal foi inspirado num conjunto de conferências de 
Roland Barthes, nas quais ele discutiu o espaço público e seus conflitos de interesses.

Nascida na República do Congo, Lisette Lagnado é Doutora em filosofia pela Universidade de São Paulo, com tese sobre Hélio Oiticica, o que ajuda a compreendermos ainda melhor as conexões entre o trabalho do artista e um dos eixos centrais do evento. Contudo, o projeto curatorial de Lagnado ${ }^{8}$ não foi recebido sem críticas, como na ideia de que seu fundamento teórico barthesiano agrupou trabalhos de uma forma articifical, excluindo conflitos inerentes à vida social (VILLAS BÔAS, 2012, p. 42).

E aqui, retornamos ao Hélio Oiticica. A Bienal toma como critério de direcionamento os caminhos estabelecidos pelo artista, sendo suas pesquisas tomadas como "documento teórico-práticos (sic), patamar de estranha atualidade para acompanhar os fenômenos da cultura" buscando "reunir uma série de elementos para dar sentido a sua mais importante investida: liquidar a representação para superar o modelo de exposições" (LAGNADO, 2006, p. 55) que ainda, nos dias de hoje, insistem no modelo tradicional. Para Bourriaud, as exposições de arte passaram de "unidade de base da qual é possível pensar as relações entre a arte e a ideologia geradas pelas técnicas em detrimento da obra individual" (BOURRIAUD, 2009, p. 100), para promotoras de encontros entre a arte e o espectador/participador e os espaços de convivência.

Como dito anteriormente, as proposições defendidas por Bourriaud já faziam parte das produções artísticas brasileiras desde o neoconcretismo dos anos 1960-1970 e é na estrutura presente na poética daquele período que a curadoria da $27^{\mathrm{a}}$ Bienal de São Paulo se apoia. Assim, segundo Sant' Anna (2010, p. 35) "a convergência conceitual entre a teoria de Bourriaud e a curadoria de Lisete Lagnado,

8 Os co-curadores foram Adriano Pedrosa (Brasil), Cristina Freire (Brasil), José Roca (Colômbia), Rosa Martínez (Espanha) e Jochen Volz (Alemanha/Brasil) 
não pode ser aplicada como um aproveitamento prático das teorias do crítico francês", sendo visível no evento uma preocupação estética que enfatiza "as relações de trocas, de tempo e espaço interpessoais, ou coletivas" (SANT’ANNA, 2010, p. 37) qual seja, a consagração da inter-relação arte e vida.

Bebendo da fonte conceitual de Parangolé que transforma o mundo em museu, redefinindo os conceitos de exposição e das instituições de arte, discutindo a territorialização do indivíduo na linguagem de novos artistas, a 27 ${ }^{\text {a }}$ Bienal de São Paulo segue o raciocínio de Rancière sobre a "partilha do sensível" e propõe a "existência de um comum e dos recortes que nele definem lugares e partes respectivas" (RANCIÈRE apud LAGNADO, 2006, p. 59) refletindo uma nova realidade referente à arte, à vida e às interconexões entre elas. A expografia do evento reflete estas metas, como na imagem a seguir. Além disso, a organizacão de seminários internacionais e residências artísticas pela Bienal atestam para a importância das trocas e de produção de conhecimento.

\section{Figura 3 - Cânone, de Marepe}

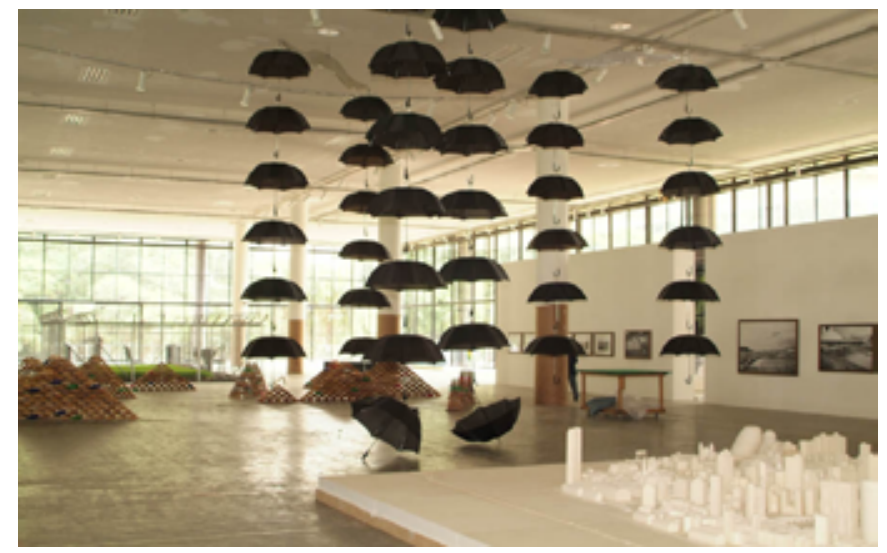

Foto: Juan Guerra - http://www.bienal.org.br/post.php?i=633

Desta forma, seja pelo viés de Nicolas Bourriaud ou pelo referencial teórico-prático de Hélio Oiticica, a 27ª Bienal de São Paulo 
reflete sobre a aproximação do público na interação entre arte e vida e aborda esta temática a partir de trabalhos atuais que levam em consideração as novas formas de convivência e as relações políticas por trás desses rizomas identitários.

Não foi apenas uma Bienal expositiva, mas uma exposição propositora, que reforça neste sentido o conceito de Bourriaud, em que a arte contemporânea não se liga mais a forma, mas a formações. Neste sentido, é importante ressaltar que como um evento que se propunha como, ou através da estética relacional, a 27ª Bienal de São Paulo não só cumpre seu papel como também dialoga perfeitamente com os trabalhos apresentados. Isso pode ser notado na forma como o público pode conduzir sua visita. Os caminhos são propostos, não estabelecidos, e desta forma, as possibilidades de trocas e relações acontecem de forma independente.

Se a estética relacional parte do ponto inicial de trocas e relações, todo o lugar torna-se possível para a arte. Segundo Bourriaud (2009, p. 83) “o que costuma chamar 'realidade' é uma montagem. Mas a montagem em que vivemos será a única possível?". A estética relacional sugere que não, e a sua consagração através da $27^{\text {a }}$ Bienal de São Paulo confirma que os caminhos têm se mostrado abertos, gerando e renovando sentido na arte. Ainda há, contudo, "oscilação entre a arte da desformalização integral e uma arte da exposição da imagem fixada, do fetiche" (LADDAGA, 2012, p. 153), revelando que o entrelaçamento entre e arte e vida é apenas uma linha-guia da arte contemporânea.

Neste contexto, o papel do curador também se mescla e tornase coletivo, pois "na medida em que as bienais se tornam maiores e mais complexas, a curadoria coletiva surge como opção de método de trabalho, [...] cria-se a possibilidade de um diálogo crítico com múltiplos pontos de vista" (PEDROSA apud LAGNADO, 2006, p. 83- 
84), mostrando que os modelos expositivos, desde sua concepção, tem se preocupado em se adaptar às poéticas da globalização.

\section{Consideracoes Finais}

Tendo a estética relacional como eixo norteador, buscou-se aproximar a produção poética de Hélio Oiticica dos anos 1960-1970, a conceitualização do tema pelo crítico francês Nicolas Bourriaud e a 27ํㅗ Bienal de São Paulo como 'validadora' deste tema da arte contemporânea.

Partindo da análise dos trabalhos de Oiticica do período de 1960-1970, é possível pensar suas práticas como fundadoras da estética relacional. Em 1967, no catálogo da exposição coletiva Nova objetividade brasileira, o artista prescreve à vanguarda brasileira estas características:

1. Vontade construtiva geral; 2. Tendência para o objeto ao ser negado e superado o quadro e o cavalete; 3. Participação do espectador: corporal, tátil, visual e semântica; 4. Abordagem e tomada de posição em relação aos problemas políticos, sociais e éticos; 5 . Tendência para uma arte coletiva e consequente abolição dos ismos; 6. Ressurgimento e novas formulações do conceito de antiarte (FREITAS, 2013, p. 67).

Assim, para Oiticica, estes termos se aplicavam ao que ele chamava de 'arte ambiental', mas conceitualmente os parâmetros poéticos utilizados eram os mesmos da estética relacional, que seria sintetizado por Nicolas Bourriaud a partir de obras de artistas europeus dos anos 1990.

Ao estabelecer como critério de análise das produções relacionais uma "teoria estética que consiste em julgar as obras de arte em função das relações inter-humanas que elas figuram, produzem ou criam (Cf. Critério de coexistência)" (BOURRIAUD, 2009, p.151), fica clara se não a dívida, ao menos a exclusão deliberada de Oiticica e outros artistas brasileiros que compartilhavam destes preceitos dos 
exemplos inspiradores para a teorização de Bourriaud, numa atitude tipicamente eurocêntrica.

A curadoria proposta por Lagnado para a $27^{\text {a }}$ Bienal de São Paulo estabelece as mesmas relações de julgamento de Bourriaud em uma proposição de "curar-junto", onde as inter-relações de diversos curadores geram múltiplos pontos de vista e, por consequência, rizomas intermináveis de relações, em uma assinatura conjunta que parte da questão relacional da arte, buscando estabelecer um diálogo de aproximação com o público.

Desta maneira, no que se refere aos diálogos entre a $27^{\text {a }}$ Bienal de São Paulo e os conceitos de Nicolas Bourriaud as aproximações convergem a partir das questões poéticas e estéticas conectadas por discussões políticas, sociais, relativas ao grupo, ao coletivo e ao interpessoal. As obras projetam novos modelos de convivência partindo de relações e interações, como uma espécie de reação ao mundo atual. Ao mesmo tempo, afastam-se do modelo de "informação que pode se dirigir a qualquer sujeito possível sem implicar em custo maior e só adquire sentido e valor para um sujeito capaz de decifrá-la e saboreála" (BOURDIEU, 2003, p.113), pois não exigem do espectador uma contemplação passiva e sim uma fruição relacional.

O evento analisado cumpriu, pois, sua função mediadora, principalmente no que se refere ao diálgo com o público ${ }^{9}$, ponto chave de todos os questionamentos propostos, seja pela 'arte ambiental' de Oiticica, ou pela estética relacional de Bourriaud, colocando o agente receptor no centro dos diálogos e criando instrumentos que garantem o acesso à obra e a ampliação de repertório do espectador/participador.

9 Um dos resultados divulgados pela Fundação Bienal foi o comparecimento de mais de 100 mil estudantes na mostra. Mérito da ação educativa realizado em paralelo com a exposição, que mostrou a preocupação em não só quantitativa, mas também qualitativa (http:// entretenimento.uol.com.br/27bienal). Este dado é o resultado de um dos pontos do projeto educativo que visava trazer "estudantes da periferia e estudantes do ensino fundamental e médio, aniosos por conhecimento e orientados previamente por professores das redes pública e privada" (COSTA apud LAGNADO; PEDROSA, 2006, p. 5). 
Há ainda uma extrapolação de conceitos, quebra-se a formalidade do espaço expositivo ampliando os espaços de trocas, através de redes, "conjuntos abertos, cujos componentes se tecem entre si" (LADDAGA, 2012, p.161). A recepção da obra deixa de depender do "controle que o receptor tem do código" (BOURDIEU, 2003, p. 120) para estabelecerse através das relações interpessoais com o objeto de arte e o contexto do lugar. Desta forma, a $27^{\mathrm{a}}$ Bienal contribuiu para o afrouxamento do controle do código, ao buscar compartilhar e dialogar com um público mais amplo.

A partir das aproximações analisadas percebe-se que as relações estabelecidadas entre a arte, suas estruturas formais e conceituais e seus agentes vêm sendo repensadas e a experiência estética passa a ser um ponto central. Atualmente, o que se vê na arte contemporânea de maneira geral, são obras que se realizam em proposições que absorvem o entorno e ganham sentido em vários lugares, tornando a linguagem global e relacionando-se com a vida. De certa forma;

[...] o que estes projetos se propõem é conceber e instrumentar mecanismos para que uma coletividade mais ou menos vasta e diversa possa regular suas interações ao mesmo tempo que se ocupa da construção de imagens e discursos em um espaço que seu próprio desenvolvimento fabrica (LADDAGA, 2012, p. 164).

Sendo assim, novos valores são introduzidos e a ausência de familiaridade com os códigos da arte, que para Bourdieu condenaria o público a "importar, em seu exercício de percepção e apreciação da obra de arte, categorias e valores extrínsecos, ou seja, precisamente as categorias e valores que organizam sua percepção cotidiana e orientam seus juízos práticos" (BOURDIEU, 2003, p. 82) passam a ser visto pela arte contemporânea como requisitos essenciais de apreciação.

Assim, como a visualidade torna-se um problema para os artistas dos anos 1960-1970 através da banalização da reprodutibilidade técnica, a construção poética volta-se para "experiência que envolve 
profunda e autenticamente o sujeito, criador ou espectador" (FREITAS, 2013, p. 167), criando-se "a vontade de dialogar com o processo de estetização do cotidiano" (FREITAS, 2013, p. 171) e instituindo com isso novas formas de interação entre arte e público, entre arte e vida. Ao fazer isso ressignifica os processos da arte, "interroga o social e o político ao extrapolar a limitação do 'objeto de arte"' (FREIRE apud LAGNADO, 2006, p. 109).

Desta forma, como a construção da obra de arte passa a depender de trocas entre as pessoas, o espaço expositivo, seja este uma galeria ou um museu "também pode servir como material bruto para um trabalho artístico" (BOURRIAUD, 2009, p.52), pois "qualquer produção, depois de ingressar no circuito das trocas, assume uma forma social que não guarda mais nenhuma relação com sua utilidade original" (BOURRIAUD, 2009, p.58), fazendo com que os objetos estéticos tornem-se instrumentos de conexão. Portanto, as aproximações entre Helio Oiticica, Nicolas Bourriaud e a 27ª Bienal de São Paulo revelam-se através de "negociações, vínculos, coexistências, [...] relações possíveis entre unidades distintas, de construção de alianças entre diferentes parceiros." (BOURRIAUD, 2009, p.63), onde a arte passa a existir através dessas trocas.

É a partir da postura confrontadora e experimental que emerge na arte dos anos 1960-1970, muito vinculada ao cenário político, que novas relações são propostas e a arte passa a criar novos mundos, fazendo com que as reflexões deste período não conduza para um estudo apenas estético, mas para uma reflexão de funcionamento deste objeto artístico na sociedade e suas relações com a instituição de arte, deixando esta de ser uma totalidade em si, mas parte de um processo maior.

A obra como documento incorpora o transitório do tempo e ensina sobre a fugacidade da vida. Como buscar a permanência de algo que definitivamente escapa? Na relação entre o objeto e o registro, a obra se torna índice de algo ausente (FREIRE apud LAGNADO, 2006, p. 113). 
Esse registro do atemporal pode fugir à sensibilidade do espectador, mas é parte da práxis do fazer artístico. Neste processo, a instituição artística entra como legitimadora do processo e valida o que pode ser confundido apenas como processos do cotidiano. Entretanto, a instituição não está limitada mais aos museus e galerias, aos espaços físicos, mas passa a ser um "território vivencial, definido por espaços densos de sentidos, onde o psíquico e o social se fundem aos traços da memória individual e coletiva" (FREIRE apud LAGNADO, 2006, p. 114). É essa relação que tanto o trabalho de Oiticica, o conceito de Bourriaud e a Bienal de São Paulo estabelecem com a arte contemporânea. As ligações e as relações entre arte e vida permitem uma expansão poética para o artista e aproximam fisicamente a arte do público. Desta forma, a ausência de algumas definições deixam lacunas que não podem ser preenchidas pelo modelo antigo, tanto da arte quanto das exposições, propondo então novos lugares para serem experimentados.

\section{REFERÊNCIAS}

BOURDIEU, Pierre. A distinção: crítica social do julgamento. São Paulo: Edusp; Porto Alegre, RS: Zouk, 2007.

BOURDIEU, Pierre. As regras da arte: gênese e estrutura do campo literário. São Paulo: Companhia das Letras, 1996.

BOURDIEU, Pierre. O amor pela arte: os museus de arte na Europa e seu público. São Paulo: Ed. Universidade de São Paulo, 2003.

BOURRIAUD, Nicolas. Estética relacional. São Paulo: Martins Fontes, 2009.

CANCLINI, Nestor Garcia. Culturas híbridas: estratégias para entrar e sair da modernidade. 3. ed. São Paulo: Ed. Universidade de São Paulo, 2000.

FIALHO, Ana Letícia. Relato da palestra de Nicolas Bourriaud, Seminário Internacional Trocas, 10 de outubro de 2006. Disponível em: <http://www.forumpermanente.org/ event_pres/simp_sem/semin-bienal/bienal-trocas/trocas-doc/copy_of_conf1>. Acesso em: 1 jun. 2015. 
FREITAS, Artur. Arte e contestação: o salão paranaense nos anos de chumbo. Curitiba: Medusa, 2013.

LAGNADO, Lisette; PEDROSA, Adriano (Ed.). 27ํㅡㄹ Bienal de São Paulo: como viver junto: guia. São Paulo: Fundação Bienal, 2006.

GINZBURG, Carlo; CASTELNUOVO, Enrico. A micro-história e outros ensaios. Lisboa: DIFEL, 1991.

IMMA. Parangolé. 1964. Disponível em: <http://www.imma.ie/en/page_236815. htm>. Acesso em: 18 fev. 2015.

LADDAGA, Reinaldo. Estética da emergência: a formação de outra cultura das artes. São Paulo: Martins Fontes, 2012.

LAGNADO, Lisette. No amor e na adiversidade. In: BIENAL DE SÃO PAULO,

27, 200627, São Paulo, SP. 27ํㅗ Bienal de São Paulo:como viver junto. São Paulo, SP: Fundação Bienal de São Paulo, 2006. p. 53-60.

MELO, Vanessa et al. Hélio Oiticica, propositor de práticas: teoria crítica sobre o Parangolé, nova objetividade e tropicália. Palíndromo, Florianópolis, v. 4, n. 8, p. 64-82, 2012. Disponível em: <http://www.revistas.udesc.br/index.php/palindromo/ article/ view/3454/2473>. Acesso em: 18 fev. 2015.

OITICICA, Helio. Museu é o mundo. Rio de Janeiro: Beco do Azougue, 2011.

OLIVEIRA, Rita. Bienal de São Paulo: impacto na cultura brasileira. São Paulo em Perspectiva, São Paulo, v. 15, n. 3, 2001.

SANT'ANNA, Susan. Discurso para uma arte relacional: análise de caso, Lisete Lagnado, Nicolas Bourriaud e a 27ª Bienal de São Paulo. 2010. 53 f. Trabalho de Conclusão de Curso (Graduação de Licenciatura em Artes Visuais) - Faculdade de Artes do Paraná, Curitiba, 2010.

VILLAS BÔAS, Glaucia. Geopolitical criteria and the classification of art. Third Text, v. 26, n. 1, p. 41-52, 2012.

QUEMIN, Alain. Le rôle des pays prescripteurs sur le marché et dans le monde de l'art contemporain. Paris: Rapport au ministère des Affaires étrangères, 2001.

TROUILLOT, Michael. North Atlantic Universals: analytical fictions, 1492-1945. South Atlantic Quaterly, v. 101, n.4, p. 839-858, 2002. 